\title{
Penerapan Konsep Multiple Intelligences pada Pembelajaran PAI
}

\author{
Fuji Zakiyatul Fikriyah', Jamil Abdul Aziz ${ }^{2}$ \\ ${ }^{1}$ Fakultas Tarbiyah, Institut Ilmu Al-Qur'an, Jakarta, Indonesia \\ ${ }^{2}$ Fakultas Tarbiyah Institut PTIQ, Jakarta, Indonesia \\ ${ }^{1}$ fujizak@gmail.com
}

\begin{abstract}
Abstrak:
Tulisan ini bertujuan menjelaskan mengenai bagaimana penerapan konsep Multiple Intelligences yang dicetuskan Howard Gardner di School of Human ( $\mathrm{SOH}$ ) pada mata pelajaran Pendidikan Agama Islam (PAI), di Bekasi Jawa Barat. Jenis penelitian ini adalah penelitian lapangan atau field research dan disajikan dalam bentuk deskriptif. Sedangkan pendekatan yang dilakukan adalah pendekatan kualitatif. Teknik pengumpulan data yang digunakan: observasi, wawancara, dan dokumentasi. Hasil penelitian menunjukkan bahwa pelaksanaan penerapan konsep multiple intelligences dalam pembelajaran pendidikan agama Islam (PAI) di SMP School Of Human (SOH) Cibubur pada kelas VIII dan IX, yaitu pelaksanaan multiple intelligences dalam pembelajaran menuntut guru harus mempunyai daya kreativitas dalam menerapkan konsep multiple intelligences. Di SMP School Of Human (SOH) Cibubur pembelajaran pendidikan agama Islam (PAI) dengan pendekatan multiple intelligences sangat bervariasi. Guru menggunakan apersepsi yang bervariasi, strategi dan metode yang beragam, serta didukung dengan penggunaan media yang kreatif.
\end{abstract}

Kata Kunci: Multiple Intelligences, Pendidikan Agama Islam, School of Human

\begin{abstract}
:
This paper aims to explain how the application of the concept of Multiple Intelligences was coined by Howard Gardner at the School of Human (SOH) on Islamic Religious Education (PAI) in Bekasi, West Java. This type of research is field research and is presented in descriptive form. While the approach taken is a qualitative approach. Data collection techniques used: observation, interviews, and documentation. The results showed that the
\end{abstract}


implementation of the concept of multiple intelligences in the learning of Islamic religious education (PAI) in Cibubur School of Human (SOH) Junior High School in grades VIII and IX, namely the implementation of multiple intelligences in learning requires teachers to have creativity in applying the concept of multiple intelligences. At SMP Cibubur's School of Human (SOH) learning Islamic religious education (PAI) with multiple intelligences approaches varies greatly. The teacher uses varied perceptions, diverse strategies and methods, and is supported by the use of creative media.

Keywords: Multiple Intelligences, Islamic Education, School of Human

\section{Pendahuluan}

Pendidikan yang selama ini berlaku di Indonesia cenderung menyamaratakan standar kecerdasan satu siswa dengan siswa lainnya dengan metode dan parameter yang sangat sempit, yaitu aspek kognitif saja. Padahal setiap manusia, dalam hal ini siswa memiliki keunikan yang berbeda-beda, pengaruh lingkungan yang melingkupi seperti lingkungan keluarga, masyarakat, sekolah, maupun lingkungan lainnya juga dapat mempengaruhi karakter dasar setiap individu. Maka, tidak heran ketika ujian akhir selesai dan kenaikan kelas menjelang sekolah membanggakan dengan kegiatan yudisium melegitimasi aneka penghargaan kepada siswa. Siswa yang unggul pada mata pelajaran matematika, ilmu pengetahuan alam dan ilmu bahasa misalnya bahasa Inggris, sementara siswa yang unggul pada bidang yang lain, misalnya mata pelajaran Pendidikan Agama Islam (PAI), bidang seni atau olah raga tidak mendapatkan apresiasi dari sekolah, meski mereka pernah mewakili sekolah pada kejuaraan di bidang tersebut.

Selanjutnya pada tahun 1980, Howard Gardner, seorang pemimpin Project Zero Havard University merumuskan teori multiple intelligences (kecerdasan majemuk). Seperti namanya, teori ini menjelaskan bahwa kompetensi kognitif manusia lebih baik dijelaskan dalam satu set kemampuan, bakat, atau keterampilan mental, yang disebut kecerdasan. Menurut Gardner, pandangan ini lebih manusiawi dan tepat dalam mecerminkan data perilaku cerdas manusia. ${ }^{1}$ Dalam teori ini gardner merumuskan ada sembilan jenis kecerdasan yang dimiliki setiap manusia. Kesembilan jenis kecerdasan tersebut adalah (1) kecerdasan linguistik (2) kecerdasan matematis-logis (3) kecerdasan visual-spasial (4) kecerdasan musik (5) kecerdasan kinestetik (6) kecerdasan interpersonal (7) kecerdasan intrapersonal (8) kecerdasan naturalis (9)

\footnotetext{
${ }^{1}$ Howard gardner, Multiple intelligences, (Jakarta: Daras Books, 2013), hal. 18
} 
kecerdaasan eksistensial. ${ }^{2}$ Kehadiran teori multiple intelligences selain menyempurnakan dan mengembangkan definisi kecerdasan, juga memperkaya metode-metode pembelajaran. Sebagaimana kita sadari bahwa dalam diri setiap manusia menghasilkan keanekaragaman intelektual dan kadar pengembangan yang berbeda. Maka, teori multiple intelligences bertujuan untuk mentransformasikan sekolah agar dapat mengakomodasi setiap siswa dengan berbagai macam pola pikirnya yang unik itu.

Selain itu, Munif Chatib, seorang pakar pendidikan Indonesia membawa paradigma baru dalam pendidikan di Negeri ini, ia mendesain model multiple intelligences yang khas Indonesia dengan berlandaskan pada konsep yang benar. Dalam bukunya Sekolah Manusia, ia menghidangkan konsep sekolah unggul dengan membawa teori multiple intelligences Howard Gardner, dimana kecerdasan dan kompetensi yang sangat beragam yang dimiliki oleh setiap siswa akan dihargai dan dianggap istimewa. Kecerdasan yang beragam tersebut digali secara terus menerus dengan cara yang tepat, maka kemudian akan muncul manusia-manusia unggul dalam bidang linguistik, visual-spasial, matematis-logis, musikal, kinestetik, interpersonal, intrapersonal, naturalis, dan eksistensial.

Memahami konsep multiple intelligences ini juga penting terutama kaitannya dengan mata pelajaran Pendidikan Agama Islam (PAI). Mata pelajaran Pendidikan Agama Islam (PAI) yang merupakan bagian dari kurikulum Pendidikan Nasional, mengemban amanah untuk ikut serta berperan menciptakan output yang berpengetahuan luas dan mendalam, beriman, dan bertaqwa kepada Allah Swt. Untuk mewujudkan tujuan tersebut guru Pendidikan Agama Islam (PAI) harus menyadari bahwa setiap peserta didik mempunyai keadaan, kemampuan, minat dan bakat yang berbeda antara yang satu dengan yang lain.

Banyak sekolah yang berhasil menerapkan multiple intelligence dalam sistem pendidikannya, salah satunya School of Human (SOH) Cibubur yang dipimpin langsung oleh Munif Chatib. School of Human ( $\mathrm{SOH}$ ) Cibubur memiliki visi "Sekolah yang menghargai setiap potensi manusia sebagai ciptaan Allah Swt. yang terbaik dengan membantu peserta didiknya menemukan profesi yang profesional sesuai dengan bakat, minat dan pandangan dunianya sehingga siap menghadapi era globalisasi dengan menjunjung tinggi akhlakul karimah”. Berdasarkan latar belakang masalah ini, kemudian penulis tertarik untuk melakukan penelitian mengenai bagaimana penerapan konsep Multiple Intelligences pada pembelajaran Pendidikan Agama Islam (PAI) Studi Kasus di SMP School of Human (SOH) Cibubur.

\footnotetext{
${ }^{2}$ Howard gardner, Multiple intelligences, hal.21
} 


\section{Dasar Teori Multiple Intelligences}

\section{Pengertian Inteligensi}

Sebelum mempelajari berbagai kecerdasan manusia yang termasuk dalam kecerdasan majemuk, ada baiknya kita mempelajari terlebih dahulu mengenai konsep definitif tentang kecerdasan itu sendiri. Ada banyak definisi kecerdasan atau inteligensi, yang sampai saat ini dipahami secara beragam oleh para ahli. Keragaman tersebut diciptakan melalui penelitian dan dengan menggunakan perspektifnya masing-masing. Meskipun para ahli merasa sulit mendefinisikannya, kecerdasan dapat dilihat dari berbagai pendekatan, yakni pendekatan teori belajar, pendekatan teori neurobiologis, pendekatan teori psikometri, dan pendekatan teori perkembangan. ${ }^{3}$

Menurut pendekatan teori belajar, kecerdasan dipandang sebagai kualitas hasil belajar, di mana pendekatan ini lebih menekankan pada perilaku yang tampak dari setiap individu. Sebagaimana menurut Cattell perilaku yang inteligen adalah yang berisi proses belajar pada fungsional tingkat tinggi. ${ }^{4}$ Hal ini berarti kecerdasan jika dipahami dengan pendekatan teori belajar, tidak ditekankan pada pengertian mengenai konsep mental dari kecerdasan, dan berarti bahwa kecerdasan bukan merupakan sifat kepribadian.

Selanjutnya, menurut pendekatan neurobiologis, kecerdasan memiliki dasar anatomis dan biologis. Hal ini berarti bahwa kecerdasan merupakan perilaku yang dapat ditelusuri dari dasar-dasar neuro-anatomis dan proses neurofisiologisnya. Dengan menggunakan pendekatan ini, dapat diketahui perbandingan antara otak orang biasa dengan otak orang cerdas. Jika diberi satu sampel untuk membandingkan antara kedua otak tersebut. Maka, hasilnya dapat ditemukan bahwa ada "brain efficiency", yaitu otak yang efisien memiliki banyak asosiasi antara neuron satu dengan yang lain, mengalami pemangkasan pada cabang-cabang neuron yang tidak diperlukan, juga aksonnya lebih besar dan mielin yang melapisinya lebih tebal. ${ }^{5}$

Sedangkan, menurut pendekatan psikometri, kecerdasan dipandang sebagai suatu konstruk hipotesis dan memiliki sifat psikologis yang berbeda pada setiap individu. Pendekatan inilah yang melahirkan tes-tes psikologi yang dikembangkan oleh tokoh pengukuran inteligensi, Alferd Binet. Maka dengan pendekatan ini pula, kecerdasan dirumuskan sebagai kemampuan umum terutama yang berkaitan dengan ingatan dan penalaran dalam mempelajari dan menghadapi masalah. ${ }^{6}$

\footnotetext{
${ }^{3}$ Eva Latipah, Psikologi Dasar Bagi Guru, (Bandung: PT Remaja Rosdakarya, 2017) hal. 115

${ }^{4}$ Eva Latipah, Psikologi Dasar Bagi Guru, hal. 115

${ }^{5}$ Eva Latipah, Psikologi Dasar Bagi Guru, hal. 116

${ }^{6}$ Eva Latipah, Psikologi Dasar Bagi Guru, hal. 116
} 
Pendekatan selanjutnya, yaitu pendekatan perkembangan. Pendekatan ini lebih menekankan perkembangan kecerdasan secara kualitatif dalam kaitannya dengan tahap-tahap perkembangan biologis individu. Salah satu tokoh dalam pendekatan ini adalah Piaget. Ia melihat adanya perbedaan kualitatif dalam cara berpikir anak pada masing-masing kelompok usia. Menurutnya, seiring bertambahnya usia seseorang, maka semakin bertambah atau meningkat kecerdasannya. ${ }^{7}$

Beberapa pendekatan di atas yang telah diuraikan satu per satu, berdampak pada perumusan makna kecerdasan menurut para ahli, mulai dari Spearman, Piaget, Alferd Binet, sampai Howard Gardner. Berikut ini adalah beberapa pengertian dari kecerdasan menurut para ahli:

Menurut Spearman (yang terkenal dengan teori Spearman), ada dua faktor pada kecerdasan, yaitu faktor umum (g) dan faktor spesifik (s). Faktor "g" mendasari hampir setiap tingkah laku mental individu, sedang faktor "s" berfungsi dalam tindakan-tindakan mental untuk mengatasi permasalahan. ${ }^{8}$

Inteligensi menurut Piaget lain lagi. Pandangan ahli perkembangan ini melihat inteligensi secara kualitatif, berdasarkan aspek isi, struktur, dan fungsinya. Untuk menjelaskan ketiga aspek tersebut, Piaget mengaitkan inteligensi dengan periodisasi perkembangan biologis, meliputi sensorimotorik, praoperasional, konkret operasional, dan abstrak operasional. Pembagian ini dimaksudkan juga sebagai periode perkembangan kognitif. Di dalam perkembangan tersebut terkandung konsep kecerdasan atau inteligensi anak. ${ }^{9}$

Alferd Binet (1857-1911) menggambarkan kecerdasan sebagai penilaian, atau disebut juga akal yang baik (good sense), berpikir praktis (practical sense), inisiatif, kemampuan diri untuk menyesuaikan diri kepada keadaan, dan kritik pada diri sendiri (auto critique). ${ }^{10}$

Definisi lain tentang inteligensi dikemukakan oleh Howard Gardner, Gardner menjelaskan inteligensi sebagai kemampuan untuk memecahkan masalah atau untuk menciptakan karya yang dihadiri dalam satu kebudayaan atau lebih. ${ }^{11}$ Gardner meyakini bahwa semua kemampuan tersebut dimiliki oleh semua manusia, meskipun manusia memiliki cara yang berbeda untuk menunjukan dan mengembangkannya. Definisi kecerdasan menurut Gardner ini sekaligus menentang anggapan “cerdas” dari sisi IQ (Intelligence Quotient) Binet.

\footnotetext{
${ }^{7}$ Eva Latipah, Psikologi Dasar Bagi Guru, hal. 116

${ }^{8}$ Wasty Soemanto, Psikologi Pendidikan Landasan Kerja Pemimpin Pendidikan, (Jakarta: Rineka Cipta, 2012), hal. 144

${ }^{9}$ Sarlito W. Sarwono, Pengantar Psikologi Umum, (Jakarta: Rajawali Pers, 2012), hal. 154

${ }^{10}$ Sarlito W. Sarwono, Pengantar Psikologi Umum, hal. 154

${ }^{11}$ Munif Chatib, Semua Anak Bintang, (Bandung: Penerbit Kaifa, 2017), hal. 5
} 
Berdasarkan beberapa definisi di atas dapat disimpulkan bahwa kecerdasan itu merupakan kemampuan yang dimiliki setiap orang untuk memecahkan suatu masalah. Karena inteligensi bersifat adaptif, yakni dapat digunakan secara fleksibel untuk merespon berbagai situasi dan masalah yang dihadapi. Istilah inteligensi juga berkaitan dengan kemampuan belajar dan pengetahuan. Seseorang yang inteligen dapat mempelajari informasi-informasi dan perilaku-perilaku baru secara lebih cepat dan lebih mudah dibandingkan dengan orang yang kurang inteligen. ${ }^{12}$

\section{Latar Belakang Konsep Multiple Intelligences}

Multiple intelligences merupakan sebuah teori yang di temukan oleh Dr. Howard Gardner pada awal tahun 1980-an. ${ }^{13}$ Sebelum teori kecerdasan multiple intelligences ini muncul, kecerdasan seseorang lebih banyak ditentukan oleh kemampuannya menyelesaikan tes IQ (Intelligence Quetient) yang berhasil dikembangkan oleh Alferd Binet pada tahun 1900, ${ }^{14}$ tes inteligensi ini seringkali melibatkan perpaduan tugas-tugas verbal dan visual yang kemudian hasil tes itu diubah menjadi angka standar kecerdasan. ${ }^{15}$

Semakin tinggi tes IQ seseorang, maka dia dikatakan memiliki kualitas kecerdasan intelektual yang tinggi, dan kemudian orang tersebut dipuji-puji sebagai orang "pintar" dan bahkan "brilian". Begitu pula sebaliknya, semakin rendah tes IQ seseorang, semakin rendah pula derajat kecerdasan intelektualnya, dan kemudian dia dicap sebagai orang bodoh. Pandangan tersebut tentu berbeda dengan dasar pemikiran dalam Islam bahwa setiap manusia diberi akal untuk berfikir. Namun, manusia memiliki keterbatasan dan hanya sedikit ilmu yang diketahui oleh manusia, disamping itu setiap manusia memiliki kemampuan berbeda-beda.

Gardner diakui telah berhasil melakukan kritik terhadap definisi kecerdasan manusia yang diwakili oleh angka-angka yang statis. Berdasarkan definisi inteligensi menurut Gardner, tes IQ yang selama ini banyak dipercaya, tidak lagi cukup mewakilinya. Sebab IQ hanya mewakili kecerdasan linguistik dan logis-matematis saja sedangkan yang lain tidak. Dalam studinya tentang kecerdasan manusia ditemukan bahwa pada hakikatnya setiap manusia memiliki tujuh (yang kemudian ditambahkan dua menjadi sembilan) spektrum kecerdasan yang berbeda-beda. Semua kecerdasan dapat dikembangkan oleh setiap orang hingga mencapai suatu tingkat yang memadai. ${ }^{16}$

\footnotetext{
${ }^{12}$ Eva Latipah, Psikologi Dasar Bagi Guru, hal. 117

${ }^{13}$ Howard Gardner, Multiple Intelligences, hal. 18

${ }^{14}$ Eva Latipah, Psikologi Dasar Bagi Guru, hal. 124

${ }^{15}$ Eva Latipah, Psikologi Dasar Bagi Guru, hal. 125

${ }^{16}$ Howard Gardner, Multiple Intelligences, hal. 36
} 
Gardner bersama rekan-rekannya melakukan penelitian untuk mengembangkan konsep multiple intelligences, agar kecerdasan setiap anak tidak hanya dinilai dengan cara menguji kemahiran seseorang memahami dan menyelesaikan soal-soal logika-matematika (sebagaimana yang dilakukan dalam tes IQ). Bersama tim, Gardner mengembangkan cara-cara mengukur kemampuan individu untuk memecahkan masalah dan menghasilkan sesuatu. ${ }^{17}$

Gardner dengan cerdas memberi label "multiple” pada luasnya makna kecerdasan. Penggunaan kata "multiple" dimaksudkan karena akan terjadinya kemungkinan bahwa ranah kecerdasan yang ditemukan terus berkembang, mulai dari tujuh kecerdasan ketika pertama kali muncul hingga saat ini menjadi sembilan kecerdasan. Pada bukunya Frames of Mind (1983) Gardner pada awalnya menemukan tujuh kecerdasan. Setelah itu, berdasarkan kriteria karakteristik konsep kecerdasan yang ia buat, Gardner menemukan kecerdasan yang kedelapan, yakni Naturalis. Dan terakhir Gardner memunculkan adanya kecerdasan yang kesembilan, yaitu kecerdasan eksistensial. ${ }^{18}$

\section{Macam-macam Multiple Intelligences}

Gardner menemukan setidaknya ada sembilan inteligensi yang dimiliki peserta didik, yaitu:

\section{Kecerdasan Verbal-Linguistik (verbal-linguistic intelligence)}

Kecerdasan verbal-linguistik atau dikenal dengan istilah pintar kata adalah kemampuan dalam menggunakan bahasa dan kata-kata baik secara lisan maupun tulisan, termasuk dalam memahami bahasa ibu dan bahasa-bahasa asing dalam mengekspresikan apa yang ada di dalam pikirannya. Menggunakan kata merupakan cara utama dalam berpikir dan menyelesaikan masalah bagi orang-orang yang memiliki kecerdasan ini, mereka juga pandai dalam memahami orang lain. ${ }^{19}$ Kemampuan ini pernah diperlihatkan oleh Abraham Lincoln, Presiden Amerika Serikat ke-16.

Gaya belajar terbaik bagi anak-anak yang memiliki kecenderungan kecerdasan linguistik adalah belajar dengan cara membaca, menulis, bercerita, merekam, mendengar, menghafal dan bertanya mengenai huruf, kata, dan kalimat. ${ }^{20}$ Oleh karena itu, ajak anak-anak ke toko buku, beri kesempatan berbicara, sediakan banyak buku-buku, rekaman, serta menciptakan peluang mereka untuk menulis.

\footnotetext{
${ }^{17}$ Nurul Hidayati Rofiah, "Menerapkan Multiple Intelligences dalam Pembelajaran di Sekolah Dasar”, dalam Jurnal Dinamika Pendidikan Dasar, Vol. 8 No.1 Maret 2016, hal. 70

${ }^{18}$ Howard Gardner, Multiple Intelligences, hal. 43

19 Muhammad Yaumi dan Nurdin Ibrahim, Pembelajaran Berbasis Kecerdasan Jamak, (Jakarta: Prenamedia Group, 2016), cet. ke-2, hal. 13

${ }^{20}$ Munif Chatib, Semua Anak Bintang, hal. 33
} 


\section{Kecerdasan Matematis-logis (logical-mathematical intelligence)}

Kecerdasan matematik disebut juga dengan kecerdasan logis, karena kecerdasan ini merupakan dasar dalam memecahkan masalah dengan memahami prinsip-prinsip yang mendasari sistem kausal atau dapat memanipulasi bilangan, kuantitas, dan operasi. ${ }^{21}$ Kecerdasan logis-matematis disebut juga dengan istilah cerdas angka termasuk juga di dalamya kemampuan ilmiah (scientific) yang sering disebut dengan berpikir jumlah kritis. Salah satu tokoh dalam kecerdasan ini adalah Albert Einstein. Cara belajar terbaik bagi anak-anak yang cerdas matematis-logis adalah melalui angka, pola-pola tertentu yang terstruktur, berpikir logika, soal cerita atau problem nyata, bereksperimen dan membuat hipotesis/ perkiraan. ${ }^{22}$

\section{Kecerdasan Visual-spasial (visual-spatial intelligence)}

Kecerdasan visual-spasial atau disebut kecerdasan visual adalah kemampuan dalam memahami gambar-gambar dan bentuk, termasuk kemampuan untuk menginterpretasi dimensi ruang yang tidak dapat dilihat. ${ }^{23}$ Maka tidak heran bila kecerdasan ini dikaitkan dengan bakat seni, khusunya seni lukis dan arsitektur. Orang dengan kecerdasan visual tinggi cenderung berpikir dengan gambar dan sangat baik ketika belajar melalui presentasi visual seperti gambar, video, dan demonstrasi dengan menggunakan alat peraga.

Anak yang memiliki kecerdasan bahasa yang tinggi umumnya ditandai dengan kemampuan menggambar ide-ide menarik, mahir membaca peta dan denah, mampu menciptakan karya seni dengan menggunakan berbagai macam media. Oleh karena itu, karier yang sesuai dengan orang yang memiliki kecerdasan visual-spasial agar kemampuannya dapat berkembang dengan baik diantaranya menjadi seorang arsitektur, penjahit, seniman, pemahat, dan sebagainya. Salah satu kemampuan ini dimiliki oleh Louis Henri Sullivan, salah satu arsitek paling berpengaruh dunia. ${ }^{24}$

\section{Kecerdasan Kinestetik (kinesthetik intelligence)}

Menurut Sonawat \& Gogri, yang dikutip oleh Muhammad Yaumi dan Nurdin Ibrahim: "Kecerdasan kinestetik adalah kemampuan untuk menggunakan seluruh tubuh dalam mengekspresikan ide, perasaan, dan menggunakan tangan untuk menghasilkan atau mentransformasi sesuatu. Kecerdasan ini mencakup keterampilan khusus seperti koordinasi,

\footnotetext{
${ }^{21}$ Muhammad Yaumi dan Nurdin Ibrahim, Pembelajaran Berbasis Kecerdasan Jamak, hal. 14

22 Munif Chatib, Semua Anak Bintang, hal. 33

${ }^{23}$ Muhammad Yaumi dan Nurdin Ibrahim, Pembelajaran Berbasis Kecerdasan Jamak, hal. 83

${ }^{24}$ Muhammad Yaumi dan Nurdin Ibrahim, Pembelajaran Berbasis Kecerdasan Jamak, hal. 15
} 
keseimbangan, ketangkasan, kekuatan, fleksibelitas dan kecepatan. Kecerdasan ini juga meliputi keterampilan untuk mengontrol gerakan-gerakan tubuh dan kemampuan untuk memanipulasi objek.",25

Anak yang memiliki kecerdasan kinestetik membutuhkan kesempatan untuk bergerak, dan menguasai gerakan. Mereka perlu didorong dalam mengembangkan motorik halusnya seperti menggunting, melipat, menjahit, menempel, merajut, menyambung, mengecat, dan menulis. Serta motorik kasar seperti berlari, melompat, berguling, merayap, dan lari jarak pendek.

\section{Kecerdasan Musikal (musical intelligence)}

Kecerdasan Musikal adalah kapasitas berpikir dalam musik untuk mampu mendengarkan pola-pola dan mengenal serta mungkin memanipulasinya. Anak-anak yang memiliki kecerdasan musik yang tinggi memiliki sensitivitas untuk mendengarkan pola-pola, bersenandung dan dapat memainkan sesuai dengan irama.

Cara belajar yang baik untuk anak yang memiliki kecenderungan kecerdasan musik adalah dengan nada, irama, dan melodi musik. ${ }^{26}$ Oleh karena itu, guru perlu memfasilitasi anak agar dapat berekspresi secara musikal dengan menggunakan alat musik ataupun dengan kegiatan-kegiatan sederhana seperti bernyanyi bersama, tepuk bernada, dan membedakan bunyi atau suara di sekitarnya.

\section{Kecerdasan Interpersonal (interpersonal intelligence)}

Gardner mendefinisikan kecerdasan interpersonal sebagai kemampuan memahami pikiran, sikap, dan perilaku orang lain. Dalam pengetian lain Mork mendefinisikan kecerdasan interpersonal dengan kemampuan untuk membaca tanda dan isyarat sosial, komunikasi verbal dan non-verbal, dan mampu menyesuaikan gaya komunikasi secara tepat. ${ }^{27}$ Kemampuan yang mencakup kecerdasan ini dimiliki oleh guru, politisi, dan pemimpin agama misalnya Gus Dur (Abdurrahman Wahid). ${ }^{28}$

Cara terbaik bagi anak yang cerdas interpersonal adalah melalui interaksi dengan orang lain, bekerja kelompok, kolaborasi, simulasi, dan berdebat. ${ }^{29}$ Anak dengan kecerdasan ini akan tampak sebagai individu yang manis, baik hati, dan suka perdamaian. Untuk mengembangkan kecerdasan ini, pendidik perlu memberikan tugas-tugas menarik yang harus diselesaikan anak secara berpasangan dan berkelompok.

\footnotetext{
${ }^{25}$ Muhammad Yaumi dan Nurdin Ibrahim, Pembelajaran Berbasis Kecerdasan Jamak, hal. 16

${ }^{26}$ Munif Chatib, Semua Anak Bintang, hal. 35

${ }^{27}$ Muhammad Yaumi dan Nurdin Ibrahim, Pembelajaran Berbasis Kecerdasan Jamak, hal. 129

${ }^{28}$ Hamzah B. Uno dan Masri Kuadrat, Mengelola Kecerdasan dalam Pembelajaran, hal. 55

${ }^{29}$ Munif Chatib, Semua Anak Bintang, hal. 35
} 


\section{Kecerdasan Intrapersonal (intrapersonal intelligence)}

Kecerdasan intrapersonal dapat didefinisikan sebagai kemampuan memahami diri sendiri dan bertindak berdasarkan pemahaman tersebut. Komponen inti dari kecerdasan ini adalah kemampuan memahami diri yang akurat meliputi kekuatan dan keterbatasan diri, kecerdasan akan suasana hati, motivasi, temperamen dan keinginin, serta kemampuan berdisiplin diri, memahami dan menghargai diri. ${ }^{30}$ Anak yang lebih menonjol kecerdasan intrapersonalnya dapat berkembang menjadi ahli penyair, motivator, psikolog, filsuf, dan sebagainya jika mendapat bimbingan dan pendidikan yang layak.

Anak-anak yang cerdas secara intrapersonal belajar melalui diri mereka sendiri, memahami dan mengekspresikan diri, dan menghubungkan materi dengan kehidupan pribadi. ${ }^{31}$ Dengan begitu, anak perlu diberi tugas yang harus dikerjakan sendiri, diberi kepercayaan untuk berkreasi, dan didorong untuk mandiri. Dorongan tumbuhnya kecerdasan intrapersonal harus disertai dengan sikap positif, memberikan pujian yang tulus, menghargai pilihan anak, serta kemauan mendengarkan cerita dan ide-ide anak merupakan stimulasi yang sesuai untuk kecerdasan intrapersonal ini.

\section{Kecerdasan Naturalis (naturalist intelligence)}

Menurut Carvin, kecerdasan naturalis adalah kemampuan seseorang dalam mengidentifikasi dan mengklasifikasi pola-pola alam (nature). Sementara, Armstrong memberi batasan tentang kecerdasan naturalistik sebagai expertise in the recognition and classification of the numerous species the flora and fauna of an individual's environment. Artinya, kecerdasan naturalistik merupakan keahlian dalam mengenal dan mengklasifikasi berbagai spesies termasuk flora dan fauna dalam suatu lingkungan. ${ }^{32}$ Anak yang memiliki kecerdasan naturalistik mempunyai ketertarikan pada dunia luar atau dunia binatang yang biasanya ditunjukan sejak usia dini.

Anak-anak dengan kecerdasan naturalis tinggi cocok dengan cara belajar di alam terbuka dengan menghubungkan flora, fauna, dan fenomena alam dengan materi belajar, dan mengaplikasikan binatang dan tanaman sebagai praktik belajar. ${ }^{33}$ Oleh karena itu untuk mendorong berkembangnya kecerdasan naturalis pada anak, pendidik jangan sampai menilai kegiatan anak di alam terbuka sebagai kegiatan yang menjijikan dan menganggap anak nakal.

\section{Kecerdasan Eksistensial (existencial intelligence)}

\footnotetext{
${ }^{30}$ Muhammad Yaumi dan Nurdin Ibrahim, Pembelajaran Berbasis Kecerdasan Jamak, hal. 18

${ }^{31}$ Munif Chatib, Semua Anak Bintang, hal. 36

${ }^{32}$ Muhammad Yaumi dan Nurdin Ibrahim, Pembelajaran Berbasis Kecerdasan Jamak, hal. 177

${ }^{33}$ Munif Chatib, Semua Anak Bintang, hal. 36
} 
Kecerdasan eksistensial adalah kemampuan untuk menempatkan diri dalam hubungannya dengan suatu kosmos yang tak terbatas dan sangat kecil serta kapasitas untuk menempatkan diri dalam hubungannya dengan fitur-fitur eksistensial dari suatu kondisi manusia seperti makna kehidupan, arti kematian, perjalanan akhir dari dunia fisik dan psikologis, dan pengalaman mendalam tentang cinta kepada orang lain atau perendaman diri secara total dalam suatu karya seni. ${ }^{34}$ Kecerdasan ini dipandang sama dengan kecerdasan spiritual walaupun belum ada petunjuk-petunjuk khusus yang diberikan oleh Gardner sebagai pencetus teori kecerdasan majemuk. Kecerdasan eksistensial mendorong orang untuk memahami proses-proses dalam konteks yang besar, luas, dan dalam yang mencakup aspekaspek estetika, filosofi, dan agama yang menekankan pada nilai-nilai keindahan klasik, kebenaran, dan kebaikan.

\section{Pembelajaran Pendidikan Agama Islam (PAI)}

\section{Pengertian Pendidikan Agama Islam (PAI)}

Pendidikan agama merupakan salah satu dari tiga subyek pelajaran yang harus dimasukkan dalam kurikulum setiap lembaga pendidikan formal di Indonesia. Hal ini karena kehidupan beragama merupakan salah satu dimensi kehidupan yang diharapkan dapat terwujud secara terpadu. ${ }^{35}$

Istilah pendidikan semula berasal dari bahasa Yunani "paedagogie", yang berarti bimbingan yang diberikan kepada anak. Istilah ini kemudian ditejemahkan dalam bahasa Inggris "education" yang berarti pengembangan atau bimbingan. ${ }^{36}$

Pendidikan dalam bahasa Arab adalah “At-Tarbiyyah” النَّبيّة dengan kata kerja rabba yang berarti pendidikan, pengasuhan, dan pemeliharaan. ${ }^{37}$ Kata kerja rabba رَبَّى yَبَّى yang

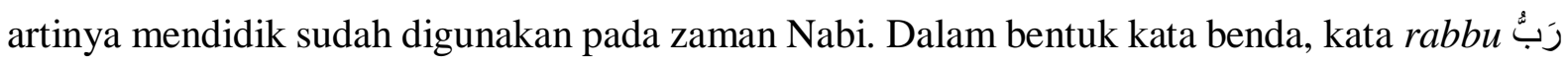
ini juga digunakan untuk Tuhan, karena Tuhan juga bersifat mendidik, mengasuh, memelihara, mencipta. Kata lain yang mengandung arti pendidikan adalah 'alama عَلَ dan addaba 38 38

Pada masa sekarang term yang paling populer adalah At-Tarbiyyah التَّرِيِّّ karena term At-Tarbiyyah التَّرِيِّة meliputi keseluruhan kegiatan pendidikan. Kata At-Tarbiyah التَّربيّة, salah satunya disebut dalam Alqurandalam Surat Ali-Imran ayat 79:39

\footnotetext{
${ }^{34}$ Muhammad Yaumi dan Nurdin Ibrahim, Pembelajaran Berbasis Kecerdasan Jamak, hal.202

${ }^{35}$ Chabib Thoha, dkk, Metodologi Pengajaran Agama, (Yogyakarta: Pustaka Pelajar, 1999), hal. 1

${ }^{36}$ Sama'un Bakry, Menggagas Ilmu Pendidikan Islam (Bandung: Pustaka Bani Quraisy, 2005), hal. 28

${ }^{37}$ Ahmad Warson Munawwir, Al-Munawwir:Kamus Arab - Indonesia, (Surabaya: Progressif, 1997), hal.

${ }^{38}$ Zakiah Daradjat, Ilmu Pendidikan Islam (Jakarta: Bumi Aksara, 1992), cet. ke-2, hal.25

${ }^{39}$ Abdul Mujib, Ilmu Pendidikan Islam, (Jakarta: Kencana, 2017), cet ke-5, hal.13
} 


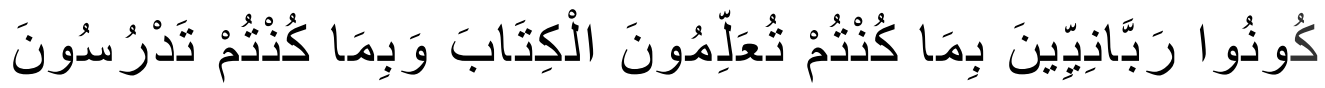

“Jadilah kamu pengabdi-pengabdi Allah karena kamu mengajarkan kitab dan karena kamu mempelajarinya.” (Q.S Ali-Imran [3]: 71)

Dalam Undang-undang Sistem Pendidikan Nasional Nomor 20 Tahun 2003 Pasal 1 Ayat 1, menjabarkan pengertian pendidikan yang berbunyi "Pendidikan adalah usaha sadar dan terencana untuk mewujudkan suasana belajar dan proses pembelajaran agar peserta didik secara aktif mengembangkan potensi dirinya untuk memiliki kekuatan spiritual keagamaan, pengendalian diri, kepribadian, kecerdasan, akhlak mulia, serta keterampilan yang diperlukan bagi dirinya, masyarakat, bangsa dan negara."40

Mahmud Yunus dalam bukunya yang berjudul "Pokok-Pokok Pendidikan dan Pengajaran", mengemukakan berbagai pengertian dari para ahli didik dan ahli filsafat mengenai pengertian pendidikan, yaitu:

1) Plato, seorang filosof Yunani. Pendidikan adalah mengasuh jasmani dan rohani supaya sampai kepada keindahan dan kesempurnaan yang mungkin dicapai.

2) Jules Simin, filosof Perancis, mengemukakan pengertian pendidikan adalah jalan untuk merubah akal menjadi akal yang lain dan mengubah hati menjadi hati yang lain.

3) John Milton, seorang ahli didik dan ahli syair bangsa Inggris, menjelaskan pendidikan yang sempurna adalah mendidik anak-anak supaya dapat melaksanakan segala pekerjaan, baik pekerjaan khusus atau pekerjaan umum dengan ketelitian, kejujuran, dan kemahiran, baik waktu aman atau waktu perang.

4) Pestalozzi, seorang ahli didik Switzerland. Pendidikan adalah menumbuhkan segala tenaga anak-anak dengan pertumbuhan yang sempurna dan seimbang.

5) Herbert Spencer, filosof pendidikan bangsa Inggris, menjelaskan pendidikan adalah menyiapkan manusia supaya hidup dengan kehidupan yang sempurna.

6) James Mill, filosof Inggris, menurutnya, pendidikan adalah menyiapkan seseorang supaya dapat membahagiakan dirinya khususnya, dan orang lain umumnya.

7) Sully, seorang filosof Inggris yang juga ahli didik dan ahli jiwa. Pendidikan adalah mensucikan tenaga tabiat anak-anak supaya dapat hidup berbudi luhur, berbadan sehat, serta berbahagia. $^{41}$

Ketujuh tokoh di atas memiliki kesamaan tujuan dalam merumuskan pengertian pendidikan. Pendidikan sama-sama diartikan sebagai usaha nyata membangun dan

40 Undang-undang Sistem Pendidikan Nasional No.20 tahun 2003 Pasal 1 Ayat 1, (Bandung: Citra Umbara, 2006), hal. 2

${ }^{41}$ Mahmud Yunus, Pokok-Pokok Pendidikan dan Pengajaran (Jakarta: PT. Hidakarya Agung, 1990), cet. ke-3, hal. 5 
menciptakan masa depan peserta didik. Melalui pendidikan yang baik, diharapkan peserta didik memiliki harapan baik bagi masa depannya.

Dari kalangan cendekiawan Islam, Al-Ghazali berpendapat bahwa pendidikan adalah proses memanusiakan manusia sejak masa kejadiannya sampai akhir hayatnya melalui berbagai ilmu pengetahuan yang disampaikan dalam bentuk pengajaran secara bertahap, dimana proses pengajaran itu menjadi tanggung jawab orang tua dan masyarakat menuju pendekatan diri pada Allah Swt. sehingga menjadi manusia yang sempurna. ${ }^{42}$

Adapun menurut Samsul Nizar menyimpulkan dari beberapa pemikiran ilmuwan bahwa pendidikan merupakan usaha sadar yang dilakukan secara bertahap dan simultan (proses), terencana yang dilakukan oleh orang yang memiliki persyaratan tertentu sebagai pendidik. Selanjutnya kata pendidikan ini dihubungkan dengan Agama Islam, dan menjadi satu kesatuan yang tidak dapat diartikan secara terpisah. Pendidikan agama Islam (PAI) merupakan bagian dari pendidikan Islam dan pendidikan Nasional, yang menjadi mata pelajaran wajib di setiap lembaga pendidikan Islam. ${ }^{43}$

Omar Mohammad Al-Toumy Al-Syaibany, seorang tokoh Islam yang dikutip oleh Ramayulis mengartikan Pendidikan Agama Islam sebagai usaha mengubah tingkah laku individu dalam kehidupan pribadinya atau kemasyarakatannya dan kehidupan dalam alam sekitarnya melalui proses kependidikan. ${ }^{44}$

Pendidikan Islam menurut Muhammad Athiyah Al-Abrasy dalam kitab At-Tarbiyah Al-Islamiyah Wa Falsafatuha adalah : "Sesungguhnya pendidikan Islam terdiri dari prinsipprinsip (demokrasi), yaitu kebebasan, persamaan, dan kesempatan yang sama dalam pembelajaran, dan untuk memperolehnya tidak ada perbedaan antara yang kaya dan yang miskin, sesungguhnya mencari ilmu bagi mereka merupakan suatu kewajiban dalam bentuk immateri, bukan untuk tujuan materi (kehendak), dan menerima ilmu itu dengan sepenuh hati dan akal mereka, dan mencarinya dengan keinginan yang kuat dari dalam dirinya, dan mereka banyak melakukan perjalanan panjang dan sulit dalam rangka memecahkan masalah-masalah agama." 45

${ }^{42}$ Abidin Ibnur Rush, Pemikiran Al-Ghazali Tentang Pendidikan (Yogyakarta: Pustaka Pelajar,1998), cet. ke-1, hal. 56

${ }^{43}$ Samsul Nizar, Pengantar Dasar-dasar Pemikiran Pendidikan Islam (Jakarta : Gaya Media Pratama, 2001), hal. 86-88

${ }^{44}$ Ramayulis, Metode Pendidikan Agama Islam, (Jakarta: Kalam Mulia, 2013), hal. 36-37

${ }^{45}$ Muhammad Athiyah Al-Abrasy, At-Tarbiyah Al-Islamiyah Wa Falsafatuha, Alih bahasa Bustami Abdul Ghani dan Djohar Bahry, (Jakarta: Bulan Bintang, 1980), hal. 29-30 
Berdasarkan pernyataan Muhammad Athiyah Al-Abrasy di atas, intinya pendidikan Islam adalah mempersiapkan individu agar ia dapat hidup dengan kehidupan yang sempurna dengan mengembangkan berfikir bebas dan mandiri serta demokratis dengan cara memperhatikan kecenderungan peserta didik secara individu yang menyangkut aspek kecerdasan akal, dan bakat dengan dititik beratkan pada pengembangan akhlak.

Dengan melihat pengertian pendidikan dan mengaitkannya dengan agama Islam, maka pendidikan agama Islam adalah usaha sadar untuk membentuk kepribadian anak didik sesuai dengan ajaran-ajaran Islam secara sistematis melalui bimbingan, pengajaran, atau latihan dalam bentuk formal maupun nonformal. Sehingga peserta didik bukan hanya dapat mengetahui dan mengerti ilmu pengetahuan yang bersifat kognitif, namun juga diharapkan dapat bertransformasi menjadi pribadi yang lebih baik dalam segi perilakunya (afektif).

Dari uraian-uraian pengertian pendidikan yang dikaitkan dengan agama Islam, maka selain pengertian Pendidikan Agama Islam dapat ditarik sebuah hal penting yakni tanggung jawab besar yang harus benar-benar disadari untuk merancang dan melaksanakan pendidikan yang bukan hanya memberikan pengetahuan yang bersifat kemampuan dasar dan khusus bagi peserta didik saja, namun perlu ditanamkan kepada para pendidik ataupun yang terlibat dalam proses pendidikan agama Islam untuk dengan sungguh-sungguh dan sepenuh hati membangun karakter peserta didik yang memiliki nilai-nilai hidup yang mulia sesuai dengan syariat agama Islam. Hal ini tak lain bertujuan adalah demi terwujudnya kehidupan manusia yang beradab dan berbudaya Islam.

\section{Fungsi dan Tujuan Pendidikan Agama Islam (PAI)}

Pendidikan agama Islam mempunyai fungsi yang sangat penting untuk pembinaan dan penyempurnaan kepribadian dan mental peserta didik. Fungsi pendidikan agama Islam berarti menyediakan segala fasilitas yang dapat memungkinkan tercapainya tugas-tugas pendidikan Islam dengan lancar. Penyediaan fasilitas ini mengandung arti dan tujuan yang bersifat struktural dan institusional. ${ }^{46}$

Nabi Saw. bersabda:

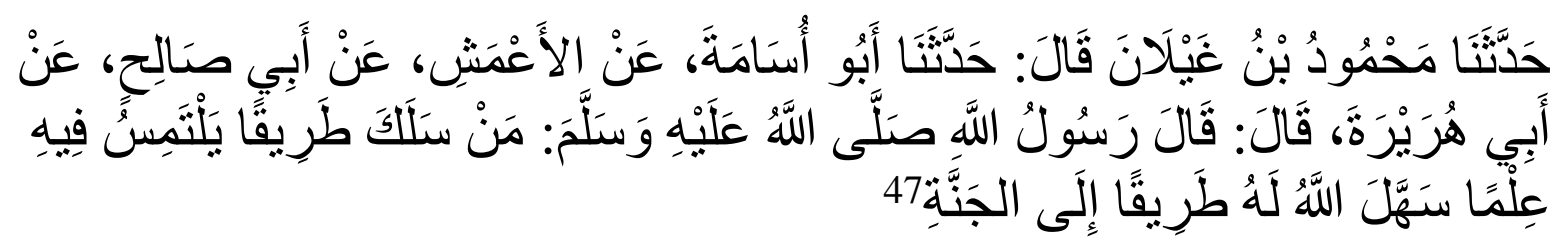

"Telah menceritakan kepada kami Mahmud Ibn Ghaylaana, ia berkata: Telah menceritakan Abu Usamah, dari Al-A'masy, dari Abi Shalih, dari Abi Hurairah, telah

\footnotetext{
${ }^{46}$ Abdul Mujib, Jusuf Mudzakkir, Ilmu Pendidikan Islam, (Jakarta: Kencana, 2017), hal. 68

${ }^{47}$ Muhammad bin 'Isa bin Saurah At-Tirmidzi, Sunan At-Tirmidzi, (Mesir: Syarikah Maktabah Wa Matba’ah Mustafa Al-Bâbî Al-Halabî, 1395 H), juz. 5 hal. 28
} 
berkata: Rasulullah Saw. bersabda: Barangsiapa yang menempuh jalan untuk mencari ilmu, maka Allah memudahkan baginya jalan masuk surga." (HR. AtTirmidzi)

Sedangkan tujuan pendidikan agama Islam sendiri yaitu mengarah pada perubahan yang ingin dicapai dalam proses pendidikan, yaitu untuk mencapai tujuan akhir dalam proses pendidikan Islam itu sendiri. ${ }^{48}$ Tujuan akhir dalam pendidikan agama Islam adalah berkaitan dengan tujuan hidup manusia, yaitu menyerahkan diri sepenuhnya kepada Allah dengan harapan tercapainya ke seimbangan dan kebahagiaan hidup baik di dunia maupun di akhirat.

Muhaimin memberikan tiga fokus tentang tujuan pendidikan agama Islam. Pertama, terbentuknya insan kamil yang mempunyai wajah-wajah qur'ani seperti wajah kekeluargaan, persaudaraan yang menumbuhkan sikap egalitarianisme, wajah yang penuh kemuliaan, wajah yang kreatif, wajah keseimbangan yang menumbuhkan kebijakan dan kearifan. Kedua, terciptanya insan kaffah yang memiliki dimensi-dimensi religius, budaya, dan ilmiah. Ketiga, penyadaran fungsi manusia sebagai hamba, khalifah Allah, serta sebagai pewaris para Nabi dan memberikan bekal yang memadai dalam rangka pelaksanaan fungsi tersebut. ${ }^{49}$

Omar Mohammad Al-Toumy Al-Syaibany juga merumuskan tujuan pendidikan agama Islam yang mencakup dalam tiga bidang asasi, yaitu:

1. Tujuan individu, mencakup perubahan yang berupa pengetahuan, tingkah laku masyarakat, tingkah laku jasmaniah dan rohani dan kemampuan-kemampuan yang harus dimiliki untuk hidup di dunia dan di akhirat.

2. Tujuan sosial, mencakup tingkah laku masyarakat, tingkah laku individu dalam masyarakat, perubahan kehidupan masyarakat, dan memperkaya pengalaman masyarakat.

3. Tujuan profesional, berkaitan dengan pendidikan dan pengajaran sebagai ilmu, seni, profesi, dan sebagai kegiatan masyarakat. ${ }^{50}$

Di samping itu Muhammad Athiyah Al-Abrasy menyebutkan ciri-ciri khusus dalam pendidikan, yaitu:

1) Membantu pembentukan akhlak yang mulia

2) Persiapan untuk mencari rejeki dan pemeliharaan dari segi-segi kemanfaatan

3) Persiapan untuk kehidupan dunia dan akhirat

\footnotetext{
${ }^{48}$ Azumardi Azra, Esei-Esei Intelektual Muslim dalam Pendidikan Islam, (Jakarta: Logos, 1999), hal. 6

49 Muhaimin, Pengembangan Kurikulum Pendidikan Agama Islam di Sekolah, Madrasah, dan Perguruan Tinggi, (Jakarta: Raja Grafindo Persada, 2005), hal. 111

50 Omar Mohammad Al-Toumy Al-Syaibany, Falsafah Pendidikan Islam (Falsafatut Tarbiyah AlIslamiyah), alih bahasa: Hasan Langgulung, (Jakarta: Bulan Biintang, 1979), hal. 399
} 
4) Menumbuhkan pengetahuan yang bersifat ilmiah pada peserta didik dan memuaskan keinginan untuk selalu mengkaji ilmu lebih mendalam

5) Menyiapkan peserta didik dari segi profesional, supaya dapat menguasai profesi tertentu dan dapat mencari rejeki dalam hidup dan hidup dengan mulia dengan memelihara segi kerohanian dan keagamaan. ${ }^{51}$

Dari uraian dan penjelasan para tokoh pendidikan di atas dapat disimpulkan bahwa pada hakikatnya tujuan pendidikan agama Islam adalah membentuk manusia yang berakidah, berakhlak mulia, berfikir, sehat jasmani dan rohaninya, serta kreatif, inisiatif, dan responsive.

\section{Ruang lingkup Pendidikan Agama Islam (PAI)}

Islam sebagai agama dan objek kajian akademik memiliki cakupan dan ruang lingkup yang luas. Mata pelajaran pendidikan agama Islam tidak bisa hanya dilihat dari aspek materi atau substansi pelajaran yang hanya mencakup aspek kognitif saja, tetapi lebih luas yaitu mencakup aspek afektif dan psikomotorik. Adapun ruang lingkup bahan pelajaran pendidikan agama Islam meliputi keserasian, keselarasan, dan keseimbangan:

a. Hubungan manusia dengan Tuhan

b. Hubungan manusia dengan dirinya sendiri

c. Hubungan manusia dengan sesama manusia dan

d. Hubungan manusia dengan makhluk lain dan lingkungan alam

Dengan mencakup lima aspek pendidikan agama Islam, meliputi: Alquran Hadits, Akidah, Akhlak, Fikih, Tarikh, yang difokuskan pada aspek:

a. Alquran, ditekankan pada kemampuan membaca, menulis, dan mengartikan surat-surat pendek.

b. Akhlak dan Keimanan, yang menekankan pada pembiasaan akhlak terpuji dan menghindari akhlak tercela.

c. Ibadah, menekankan pada cara melakukan ibadah dan mu'amalah yang baik dan benar. ${ }^{52}$

Dengan melihat ruang lingkupnya diatas, jelaslah bahwa dengan pendidikan Islam kita berusaha untuk membentuk manusia yang berkepribadian kuat dan baik (akhlakul karimah)

51 Muhammad Athiyah al-Abrasyi, at-Tarbiyah al-Islamiyah wa Falsafatuha, Alih bahasa Bustami Abdul Ghani dan Djohar Bahry, hal. 197

52 Keputusan Menteri Agama RI Nomor 211 tahun 2011 tentang Pedoman Pengembangan Standar Nasional Pendidikan Agama Islam pada Sekolah, hal. 5-6 
juga memiliki ilmu-ilmu yang berdasarkan pada ajaran agama Islam. Oleh karena itulah, pendidikan Islam sangat penting sebab dengan pendidikan Islam, orang tua atau guru sebisa mungkin mengarahkan anak untuk membentuk kepribadian yang sesuai dengan ajaran Islam.

\section{Multiple Intelligences dalam Pembelajaran Pendidikan Agama Islam (PAI)}

Teori multiple intelligences telah digunakan dan dikembangankan dalam sistem pendidikan di Amerika Serikat, dan memberikan banyak pengaruh pada perkembangan sistem pendidikan di negara tersebut. Penerapan teori multiple intelligences dalam pendidikan telah banyak memberikan pengaruh dalam proses berlajar mengajar yang melibatkan siswa dan guru. Gardner menemukan banyak siswa yang kecewa atau kurang puas dengan cara mengajar guru mereka di sekolah, rasa kecewa dan tidak puas tersebut salah satunya disebabkan oleh guru seringkali monoton dalam mengajar sebab ia mengajar hanya menggunakan satu model, yakni yang sesuai dengan kecerdasan yang dimilikinya saja, padahal siswa memiliki kecerdasan beragam dan berbeda antara satu dengan yang lain. ${ }^{53}$

Pengaplikasian multiple intelligences juga berlaku pada mata pelajaran pendidikan agama Islam (PAI) di sekolah / madrasah. Multiple intelligences mampu menjembatani proses pengajaran yang membosankan menjadi suatu pengalaman belajar yang menyenangkan dan siswa tidak hanya dijelajahi oleh teori semata, melainkan pengalaman berdasarkan kecerdasan yang mereka miliki, selain itu semakin bertambahnya pengetahuan agama siswa terutama dalam mata pelajaran PAI baik ranah kognitif, afektif, ataupun psikomotorik berdasarkan kecerdasan yang ada pada masing-masing peserta didik.

Langkah awal dalam penerapan stategi multiple intelligences pada pembelajaran pendidikan agama Islam (PAI) sama dengan umumnya penerapan multiple intelligences dalam mata pelajaran lainnya. Langkah pertama yang perlu dilakukan guru pendidikan agama Islam (PAI) sebelum memulai program pengajarannya adalah mengetahui terlebih dahulu kecenderungan kecerdasan masing-masing peserta didik yang akan diajarnya dengan menggunakan multiple intelligences research (MIR). ${ }^{54}$ Saat ini telah banyak cara yang dikembangkan untuk mengidentifikasi kecerdasan majemuk siswa, baik yang disusun berdasarkan sistem komputerisasi maupun yang masih menggunakan cara tradisional dengan melakukan pengamatan terhadap kebiasaan orang.

\section{Hasil Penelitian}

${ }^{53}$ Howard gardner, Multiple Intelligences, hal. 42

${ }^{54}$ Munif Chatib, Semua anak Bintang, hal. 11 
Pembelajaran dengan pendekatan multiple intelligences menjadi program kurikulum di SMP School of Human (SOH) Cibubur. Sebagaimana data yang diperoleh peneliti dari dokumen pribadi SMP School of Human ( $\mathrm{SOH}$ ) Cibubur. Hal tersebut juga dipertegas oleh Kepala Sekolah SMP School of Human (SOH) Cibubur, Bapak Akbar Sujono, bahwa konsep kurikulum di SMP School of Human (SOH) Cibubur memadukan antara kurikulum nasional selain itu dengan menggunakan pendekatan multiple intelligences. ${ }^{55}$

Untuk pelaksanaan pembelajaran di SMP School of Human (SOH) Cibubur khususnya kelas VIII dan IX menggunakan metode pembelajaran dengan menyesuaikan kecerdasan siswa. Seperti yang diungkapkan oleh Guru Mata Pelajaran pendidikan agama Islam (PAI), Bapak Irsan Qodriansyah bahwa proses pembelajarannya mengunakan metode yang disesuaikan dengan cara belajar anak, yaitu dengan cara dipadukan diantara kecerdasan yang ada, bisa dengan menggunakan media visual, aktivitas games atau ice breaking, dan lain sebagainya. ${ }^{56}$

Dalam mata pelajaran PAI itu sendiri dengan digunakannya pedekatan multiple intelligences siswa menjadi lebih antusias dalam belajar. Siswa juga mudah memahami pelajaran PAI. Kemudian pada penelitian ini penulis juga berkesempatan mewawancarai siswa SMP School of Human (SOH) Cibubur, bahwa pembelajaran dengan menggunakan pendekatan multiple intelligences dinilai sebagai pembelajaran yang menyenangkan, siswa merasa lebih antusias serta model maupun metode yang digunakan sangat variatif, yang disesuaikan dengan gaya belajar anak. ${ }^{57}$ Jadi bukan anak yang menyesuaikan gaya belajar guru, tetapi guru yang menyesuaikan belajar anak.

Untuk lebih jelas dalam penerapan konsep multiple intelligences dalam pembelajaran PAI pada siswa kelas VIII dan IX di SMP School of Human (SOH) Cibubur, dapat dibagi dalam tiga tahap, yaitu:

\section{Perencanaan Pembelajaran}

Dalam penerapan pembelajaran berbasis multiple intelligences memerlukan persiapan yang matang untuk mendapatkan hasil yang maksimal. Oleh karena itu, guru perlu mengikuti langkah-langkah atau prosedur tertentu yang sesuai dengan teori multiple intelligences dalam menerapkannya. Langkah pertama yaitu mengenal jenis kecerdasan siswa. Kecerdasan siswa

\footnotetext{
24 Juli 2018 24 Juli 2018

${ }^{56}$ Wawancara dengan Guru PAI SMP School of Human (SOH) Cibubur, Irsan Qodriansyah Z., Cibubur,

57 Wawancara dengan Siswa Kelas VIII SMP School of Human (SOH) Cibubur, Zahra, Cibubur, 2 Agustus 2018
}

${ }^{55}$ Wawancara dengan Kepala Sekolah SMP School of Human (SOH) Cibubur, Akbar Sujono, Cibubur, 
dapat diketahui antara lain melalui: tes, mengamati kegiatan siswa di dalam kelas, mengamati kegiatan siswa di luar kelas, serta mengetahui dan memahami data-data siswa. ${ }^{58}$

Berdasarkan hasil wawancara dengan Pak Akbar Sujono, selaku kepala sekolah SMP School of Human (SOH) Cibubur dan juga pengamatan di lapangan yang peneliti lakukan menunjukan sebagian besar langkah-langkah awal tersebut sudah dilakukan. Dalam penerimaan siswa baru di SMP School of Human (SOH) Cibubur, dilakukan penelitian terlebih dahulu menggunakan metode MIR (Multiple Intelligence Research), untuk mengetahui minat, bakat, dan kelebihan masing-masing anak sehingga guru bisa mengembangkan dan menyalurkan masing-masing anak sesuai dengan minat dan kecerdasannya. ${ }^{59}$

Dari hasil MIR yang dilakukan oleh pihak sekolah, diketahui bahwa pada siswa kelas VIII memiliki dominan kecerdasan visual-spasial, kinestetik, interpersonal, naturalis, logismatematis, linguistik, dan intrapersonal. Sedangkan pada siswa kelas IX hasil MIR yang didapat adalah siswa memiliki dominasi kecerdasan visual-spasial, musik, kinestetik, interpersonal, naturalis, logis-matematis, linguistik, dan intrapersonal. ${ }^{60}$

Selanjutnya langkah kedua dalam perencanaan pembelajaran berbasis multiple intelligences yaitu menyusun RPP yang sesuai dengan jenis kecerdasan siswa. Dalam setiap RPP yang dibuat guru, di dalamnya mencakup langkah-langkah proses pembelajarannya yaitu:

1) Kegiatan awal:

a) Membuka pelajaran dengan doa dan salam

b) Melakukan apersepsi, istilah jika dalam multiple intelligences disebut alpha zone yang artinya memberi semangat agar siswa siap belajar serta memberi pengenalan materi yang akan disampaikan dengan cara menyenangkan,

2) Kegiatan Inti.

Pada kegiatan ini meliputi eksplorasi, elaborasi, konfirmasi. Dengan variasi metode pembelajaran.

3) Kegiatan penutup

Memberikan kesimpulan pelajaran, mengapresiasi aktifitas siswa dalam belajar, serta memberikan motivasi pada siswa untuk terus belajar. ${ }^{61}$ hal. 79

${ }^{58}$ Paul Suparno, Teori Intelligensi Ganda dan Aplikasinya di sekolah, (Yogyakarta: Kanisisus, 2004),

${ }^{59}$ Wawancara dengan Kepala Sekolah SMP School of Human (SOH) Cibubur, Akbar Sujono, Cibubur, 24 Juli 2018

${ }^{60}$ Hasil Multiple Intelligence Research (MIR) yang dilakukan SMP School of Human (SOH) Cibubur

${ }^{61}$ Dokumentasi RPP siswa SMP School of Human (SOH) Cibubur. 
RPP yang dibuat harus berusaha mencakup beberapa kecerdasan dominan dari hasil MIR yang telah diketahui oleh guru. Untuk keterangan lebih jelas, RPP dapat dilihat dalam lampiran.

Dalam penerapannya, kegiatan belajar mengajar di SMP School of Human (SOH) Cibubur tidak menggunakan sistem satu ruang kelas dengan satu jenis kecerdasan. Namun, walaupun dalam menjalankan kegiatan pembelajaran tidak menggunakan sistem satu ruang kelas dengan satu jenis kecerdasan, guru bisa menggunakan cara lain, yaitu lebih fokus pada model aktifitas pembelajaran yang dirancang secara unik dan menarik. ${ }^{62}$ Aktifitas belajar siswa disesuaikan berdasarkan analisa hasil MIR yang telah dilakukan pada awal penerimaan siswa baru.

Menurut Pak Irsan Qodriansyah, selaku guru Pendidikan Agama Islam (PAI), karena peserta didik di kelas lebih dominan pada kecerdasan visual, maka guru biasa menggunakan media-media visual sebagai media pembelajaran dalam penyampaian materi. Selain mengakomodasi peserta didik dengan kecerdasan visual-spasial, guru juga mengkombinasikan metode dan strategi pembelajaran yang dapat diterapkan untuk mengakomodasi kecerdasankecerdasan yang lain, misalnya pada peserta didik yang memiliki kecerdasan kinestetik, bisa menggunakan aktivitas icebreaking, untuk peserta didik dengan kecerdasan linguistik pembelajaran bisa menggunakan metode mind map dan lain-lain. ${ }^{63}$

\section{2) Pelaksanaan Pembelajaran}

Mengingat ruang lingkup dan bidang studi dalam pembelajaran Pendidikan Agama Islam (PAI) di SMP dirangkum dalam satu mata pelajaran, maka penjabaran kegiatan pembelajarannya tidak dijelaskan dalam masing-masing bidang studi tersebut. Hasil pengamatan terhadap pembelajaran pendidikan agama Islam (PAI) dapat dijelaskan sebagai berikut:

Guru membuka pembelajaran dengan apersepsi dan tes fokus guna menyamakan fokus semua peserta didik sebelum memulai pembelajaran. Tes fokus yang dilakukan adalah permainan dragon tail. Setelah melakukan apersepsi, guru menayangkan video yang berjudul: Kerusakan Bumi Akibat Manusia dan memutar lagu berbahasa arab tentang kemanusiaan. Selanjutnya, guru meminta masing-masing siswa untuk memberikan komentar pada video yang sudah ditayangkan. Guru memberikan penjelasan mengenai video yang ditayangkan,

\footnotetext{
${ }^{62}$ Munif Chatib, Sekolahnya Manusia, hal. 119

${ }^{63}$ Wawancara dengan Guru PAI SMP School of Human (SOH) Cibubur, Irsan Qodriansyah Z., Cibubur,
} 24 Juli 2018 
bahwa semua kerusakan yang dilakukan oleh manusia dikarenakan manusia tidak mengenal siapa Tuhannya.

Selanjutnya guru menayangkan video mengenai penjelasan iman kepada kitab-kitab Allah dan mengenai pengertian Alquransendiri. Setelah penayangan video selesai, guru meminta masing-masing murid untuk memberikan pengertian atau kutipan mengenai kitab Allah khususnya Alquranmenurut pendapatnya masing-masing dan kemudian ditempel pada karton untuk dijadikan mading kelas. ${ }^{64}$

Dari hasil pengamatan di atas dapat dijelaskan bahwa proses pembelajaran di atas dapat mengakomodasi kecerdasan linguistik, visual-spasial, kinestetik, dan interpersonal.

Pada pengamatan pembelajaran PAI di kelas lain, yaitu pada kelas IX dengan tema Iman Kepada Allah, ditemukan proses pembelajaran yang berbeda. Hasil pengamatan tersebut dapat dipaparkan sebagai berikut:

Pelajaran dimulai dengan berdoa bersama. Selanjutnya guru sedikit mengulas materi yang telah dipelajari pada minggu sebelumnya. Lalu melakukan apersepsi dengan estafet ayatayat Alquranalpada juz 30. Setelah melaukan aktivitas apersepsi, guru menayangkan video mengenai gempa di Nusa Tenggara Barat yang baru saja terjadi dan menjelaskan hikmah dan pelajaraan yang dapat diambil dari kejadian tersebut.

Selanjutnya guru menayangkan video yang berisi materi pelajaran. Disela-sela penjelasan materi, guru juga sesekali melemparkan pertanyaan kepada peserta didik. Dan sebaliknya, sesekali peserta didik juga bertanya kepada guru mengenai materi yang sedang dijelaskan. Selanjutnya, guru memberikan tugas pada peserta didik untuk membuat mind map atau rangkuman mengenai materi pembelajaran yang sudah disampaikan. Pada akhir mata pelajaran guru mengajak para untuk berdonasi bagi para korban bencana alam di Nusa Tenggara Barat yang dikumpulkan oleh salah satu siswa di kelas. ${ }^{65}$

Melalui proses pembelajaran tersebut siswa akan terlatih dalam mengembangkan kecerdasan linguistik, visual-spasial, kinestetik, intrapersonal, dan eksistensial.

\section{3) Evaluasi}

Hasil Wawancara dengan Guru pendidikan agama Islam (PAI) School of Human (SOH) Cibubur menunjukan bahwa secara konsep, evaluasi atau penilaian pembelajaran yang dikembangkan mengacu pada penilaian autentik, di mana dalam penilaian ini mencakup tiga aspek kemampuan, yaitu kognitif, afektif, dan psikomotorik. Berikut hasil wawancara tersebut:

${ }^{64}$ Observasi Kelas VIII, 30 Juli 2018

${ }^{65}$ Observasi Kelas IX, 6 Agustus 2018 
Untuk perihal penilaian, di School of Human (SOH) Cibubur meliputi tiga aspek, yaitu: kognitif, afektif, dan psikomotorik. Untuk kognitif dilihat dari nilai akademis dan sejauh mana peserta didik mampu menjawab pertanyaan-pertanyaan di kelas setiap harinya. Untuk penilaian psikomotorik dilihat sejauh mana tingkat keterampilan atau konten yang dibuat peserta didik. Penilaian ini dibagi ke dalam tiga poin, yaitu kerja, karya, dan projek. Aktivitas dalam poin kerja contohnya ialah presentasi. Karya bisa berupa mind map, poster, membuat film atau vlog. Sedangkan, untuk projek diisi dengan aktivitas diskusi, debat, dan lain sebagainya. Selanjutnya dalam penilaian afektif juga dibagi dalam tiga tahap. Pertama, setiap satu bulan satu kali, peserta didik diberikan form untuk menilai sikap mereka sendiri. Kedua, masing-masing peserta didik dinilai oleh temannya. Ketiga, Guru memberikan penilaian langsung kepada peserta didik. ${ }^{66}$

\section{Kesimpulan}

Berdasarkan hasil penelitian yang penulis lakukan mengenai penerapan konsep multiple intelligences dalam pembelajaran Pendidikan Agama Islam (PAI) di SMP School of Human ( $\mathrm{SOH}$ ) Cibubur, melalui teknik pengumpulan data dengan berbagai metode, kemudian mengolah dan menganalisis data sebagaimana telah peneliti paparkan pada bab-bab sebelumnya, maka dapat ditarik kesimpulan sebagai berikut:

Pelaksanaan penerapan konsep multiple intelligences dalam pembelajaran Pendidikan Agama Islam (PAI) di SMP School of Human (SOH) Cibubur dimulai dengan dilakukannya Multiple Intelligences Research (MIR) yang diperuntukkan bagi siswa pada saat penerimaan siswa baru. Dalam penerapannya, pelaksanaan multiple intelligences dalam pembelajaran Pendidikan Agama Islam (PAI) menuntut guru harus mempunyai daya kreativitas. Di SMP School of Human (SOH) Cibubur pembelajaran Pendidikan Agama Islam (PAI) dengan konsep multiple intelligences sangat bervariasi. Guru menggunakan apersepsi yang kreatif, variasi strategi dan metode yang beragam, serta didukung dengan penggunaan media yang kreatif, ada yang menggunakan strategi visualisasi, kerjasama kelompok, berbagai permainan, presentasion, membuat video atau film, dan sebagainya. Sehingga dalam penyampaian materi, siswa langsung menjadi subyek. Ini akan menjadi pembelajaran yang menyenangkan dan bermakna.

Proses pelaksanaan penerapan konsep multiple intelligences dalam pembelajaran Pendidikan Agama Islam (PAI) sudah berjalan dengan baik, sudah sesuai denga prinsip konsep

${ }^{66}$ Wawancara dengan Guru PAI SMP School of Human (SOH) Cibubur, Irsan Qodriansyah Z., Cibubur, 
pembelajaran multiple intelligences, bahwa tidak ada anak yang bodoh, semua anak cerdas dengan kecenderungan kecerdasan mereka masing-masing, dan sudah dengan kosnep pembelajaran yang menekankan pada the best process dan the best input. Best process berarti proses pembelajaran harus mempunyai kualitas yang didasarkan pada strategi dan metode pemberian materi, bahan atau media serta kemampuan guru dalam menerapkan kepada siswa. Sedangkan best output merupakan hasil pembelajaran, bila siswa enjoy, dapat menikuti pembelajaran dengan perasaan senang dan semangat, serta aktif maka hasilnya pun akan baik.

\section{Saran}

Terlepas dari keterbatasan yang dimiliki, hasil penelitian ini diharapkan pengaruh yang luas untuk penelitian selanjutnya dengan topik serupa. Penelitian ini bisa dikembangkan lebih jauh oleh para akademisi bidang pendidikan untuk digali lebih dalam tentang bagaimana penerapan konsep multiple intelligences dalam pembelajaran pendidikan agama Islam (PAI) dan pengaruhnya dalam penguasaan materi siswa. 


\section{Daftar Pustaka}

Howard Gardner, Multiple intelligences, (Jakarta: Daras Books, 2013)

Eva Latipah, Psikologi Dasar Bagi Guru, (Bandung: PT Remaja Rosdakarya, 2017)

Wasty Soemanto, Psikologi Pendidikan Landasan Kerja Pemimpin Pendidikan, (Jakarta: Rineka Cipta, 2012)

Sarlito W. Sarwono, Pengantar Psikologi Umum, (Jakarta: Rajawali Pers, 2012)

Munif Chatib, Semua Anak Bintang, (Bandung: Penerbit Kaifa, 2017)

Nurul Hidayati Rofiah, "Menerapkan Multiple Intelligences dalam Pembelajaran di Sekolah Dasar”, dalam Jurnal Dinamika Pendidikan Dasar, Vol. 8 No.1 Maret 2016

Muhammad Yaumi dan Nurdin Ibrahim, Pembelajaran Berbasis Kecerdasan Jamak, (Jakarta: Prenamedia Group, 2016), cet. ke-2

Muhammad Yaumi dan Nurdin Ibrahim, Pembelajaran Berbasis Kecerdasan Jamak, hal. 14

Paul Suparno, Teori Intelligensi Ganda dan Aplikasinya di sekolah, (Yogyakarta: Kanisisus, 2004)

Chabib Thoha, dkk, Metodologi Pengajaran Agama, (Yogyakarta: Pustaka Pelajar, 1999)

Sama'un Bakry, Menggagas Ilmu Pendidikan Islam (Bandung: Pustaka Bani Quraisy, 2005)

Ahmad Warson Munawwir, Al-Munawwir:Kamus Arab - Indonesia, (Surabaya: Progressif, 1997)

Zakiah Daradjat, Ilmu Pendidikan Islam (Jakarta: Bumi Aksara, 1992), cet. ke-5

Undang-undang Sistem Pendidikan Nasional No.20 tahun 2003 Pasal 1 Ayat 1, (Bandung: Citra Umbara, 2006)

Mahmud Yunus, Pokok-Pokok Pendidikan dan Pengajaran (Jakarta: PT. Hidakarya Agung, 1990), cet. ke-3

Abidin Ibnur Rush, Pemikiran Al-Ghazali Tentang Pendidikan (Yogyakarta: Pustaka Pelajar,1998), cet. ke-1

Samsul Nizar, Pengantar Dasar-dasar Pemikiran Pendidikan Islam (Jakarta : Gaya Media Pratama, 2001)

Ramayulis, Metode Pendidikan Agama Islam, (Jakarta: Kalam Mulia, 2013)

Muhammad Athiyah Al-Abrasy, At-Tarbiyah Al-Islamiyah Wa Falsafatuha, Alih bahasa Bustami Abdul Ghani dan Djohar Bahry, (Jakarta: Bulan Bintang, 1980)

Abdul Mujib, Jusuf Mudzakkir, Ilmu Pendidikan Islam, (Jakarta: Kencana, 2017)

Muhammad bin 'Isa bin Saurah At-Tirmidzi, Sunan At-Tirmidzi, (Mesir: Syarikah Maktabah Wa Matba'ah Mustafa Al-Bâbî Al-Halabî, 1395 H) 
Fuji Zakiyatul Fikriyah dan Jamil Abdul Aziz

Azyumardi Azra, Esei-Esei Intelektual Muslim dalam Pendidikan Islam, (Jakarta: Logos, 1999 Muhaimin, Pengembangan Kurikulum Pendidikan Agama Islam di Sekolah, Madrasah, dan Perguruan Tinggi, (Jakarta: Raja Grafindo Persada, 2005)

Omar Mohammad Al-Toumy Al-Syaibany, Falsafah Pendidikan Islam (Falsafatut Tarbiyah Al-Islamiyah), alih bahasa: Hasan Langgulung, (Jakarta: Bulan Biintang, 1979) 